\title{
Life cycle assessment of stormwater management in the context of climate change adaptation
}

\author{
Brudler, Sarah; Arnbjerg-Nielsen, Karsten; Hauschild, Michael Zwicky; Rygaard, Martin
}

Published in:

Water Research

Link to article, DOI:

10.1016/j.watres.2016.10.024

Publication date:

2016

Document Version

Peer reviewed version

Link back to DTU Orbit

Citation (APA):

Brudler, S., Arnbjerg-Nielsen, K., Hauschild, M. Z., \& Rygaard, M. (2016). Life cycle assessment of stormwater management in the context of climate change adaptation. Water Research, 106, 394-404.

https://doi.org/10.1016/j.watres.2016.10.024

\section{General rights}

Copyright and moral rights for the publications made accessible in the public portal are retained by the authors and/or other copyright owners and it is a condition of accessing publications that users recognise and abide by the legal requirements associated with these rights.

- Users may download and print one copy of any publication from the public portal for the purpose of private study or research.

- You may not further distribute the material or use it for any profit-making activity or commercial gain

- You may freely distribute the URL identifying the publication in the public portal 


\section{Accepted Manuscript}

Life cycle assessment of stormwater management in the context of climate change adaptation

Sarah Brudler, Karsten Arnbjerg-Nielsen, Michael Zwicky Hauschild, Martin Rygaard

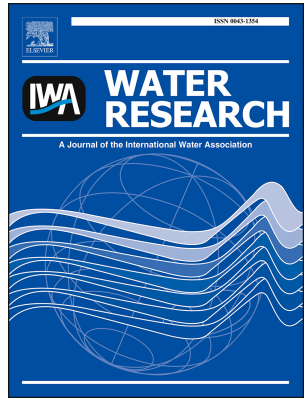

PII: $\quad$ S0043-1354(16)30776-X

DOI: $\quad$ 10.1016/j.watres.2016.10.024

Reference: WR 12422

To appear in: Water Research

Received Date: 20 June 2016

Revised Date: 7 October 2016

Accepted Date: 8 October 2016

Please cite this article as: Brudler, S., Arnbjerg-Nielsen, K., Hauschild, M.Z., Rygaard, M., Life cycle assessment of stormwater management in the context of climate change adaptation, Water Research (2016), doi: 10.1016/j.watres.2016.10.024.

This is a PDF file of an unedited manuscript that has been accepted for publication. As a service to our customers we are providing this early version of the manuscript. The manuscript will undergo copyediting, typesetting, and review of the resulting proof before it is published in its final form. Please note that during the production process errors may be discovered which could affect the content, and all legal disclaimers that apply to the journal pertain. 
Scenario 1

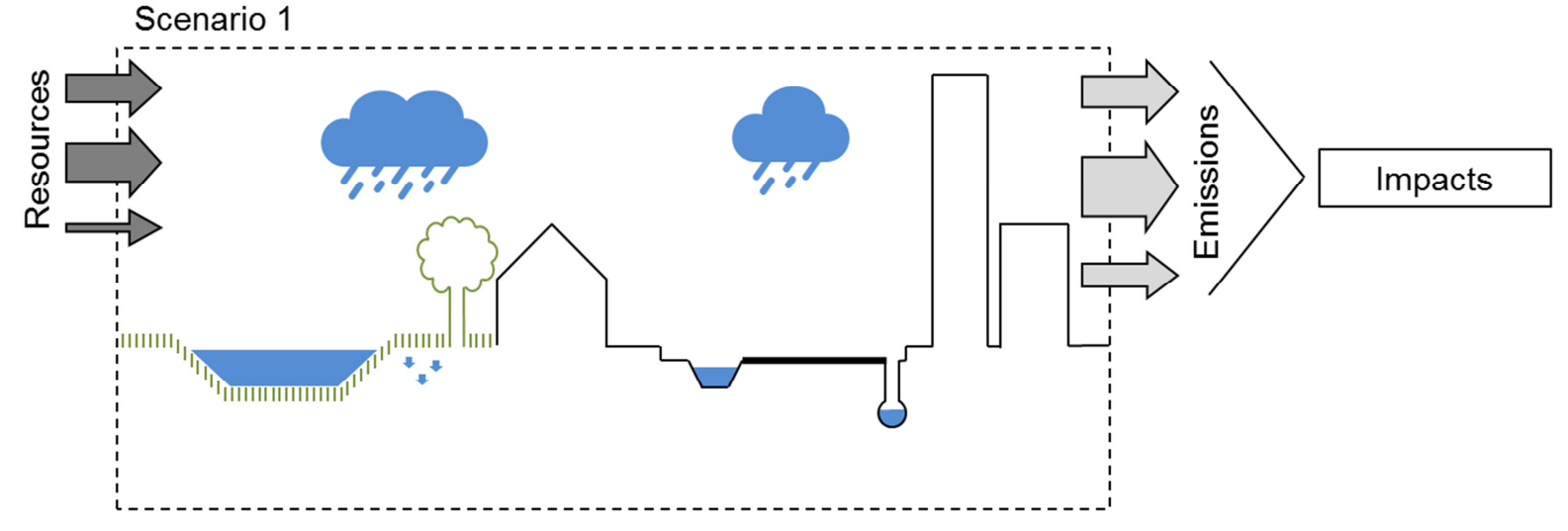

Scenario 2

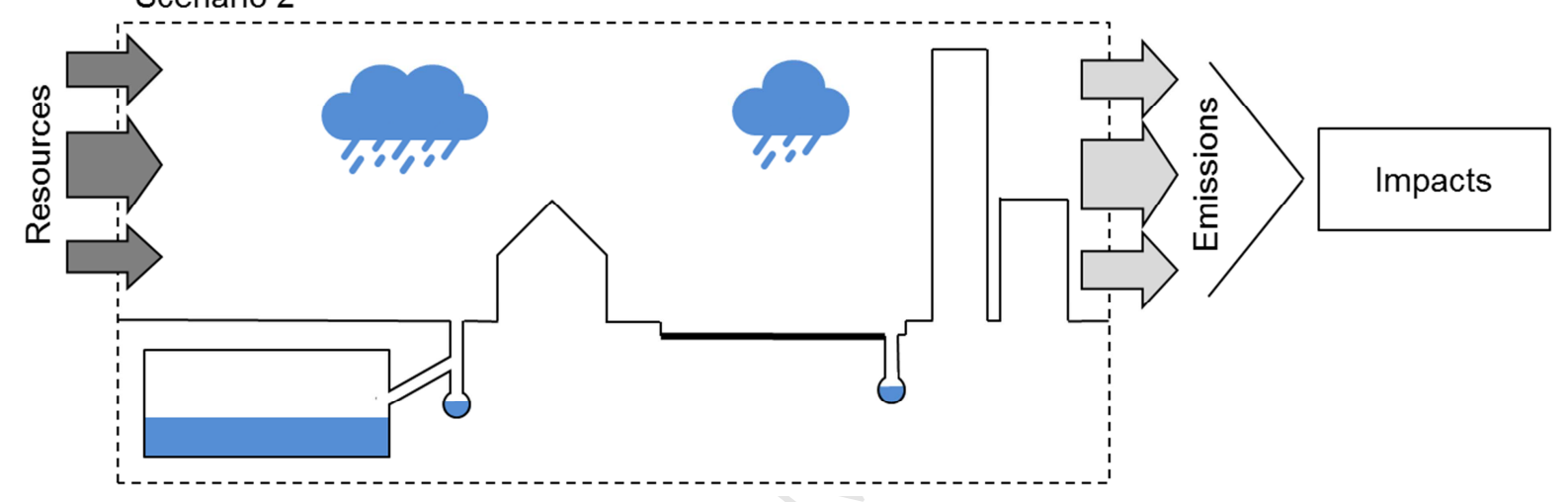




\section{Life cycle assessment of stormwater management in the context of climate change adaptation}

1 Authors: Sarah Brudler ${ }^{*, * *}$, Karsten Arnbjerg-Nielsen*, Michael Zwicky

2 Hauschild***, Martin Rygaard* $^{*}$

3 * Urban Water Systems, Department of Environmental Engineering,

4 Technical University of Denmark

$5^{* *}$ VCS Denmark

$6{ }^{* * *}$ Quantitative Sustainability Assessment, Department of Management

7 Engineering, Technical University of Denmark

8 Keywords: allocation, environmental impact, flood protection, functional

9 unit, LCA, Three Points Approach

10 Abstract

11 Expected increases in pluvial flooding, due to climatic changes, require

12 large investments in the retrofitting of cities to keep damage at an

13 acceptable level. Many cities have investigated the possibility of

14 implementing stormwater management (SWM) systems which are multi-

15 functional and consist of different elements interacting to achieve desired

16 safety levels. Typically, an economic assessment is carried out in the

17 planning phase, while environmental sustainability is given little or no

18 attention. In this paper, life cycle assessment is used to quantify 
19 environmental impacts of climate change adaptation strategies. The

20 approach is tested using a climate change adaptation strategy for a

21 catchment in Copenhagen, Denmark. A stormwater management system,

22 using green infrastructure and local retention measures in combination

23 with planned routing of stormwater on the surfaces to manage runoff, is

24 compared to a traditional, sub-surface approach. Flood safety levels

25 based on the Three Points Approach are defined as the functional unit to

26 ensure comparability between systems. The adaptation plan has

27 significantly lower impacts ( $3-18$ person equivalents/year) than the

28 traditional alternative (14 - 103 person equivalents/year) in all analysed

29 impact categories. The main impacts are caused by managing rain events

30 with return periods between 0.2 and 10 years. The impacts of handling

31 smaller events with a return period of up to 0.2 years and extreme events

32 with a return period of up to 100 years are lower in both alternatives. The

33 uncertainty analysis shows the advantages of conducting an

34 environmental assessment in the early stages of the planning process,

35 when the design can still be optimised, but it also highlights the

36 importance of detailed and site-specific data.

\section{1. Introduction}

38 Climate change (CC) is expected to change the volume and pattern

39 of precipitation in the future (IPCC, 2014). In particular, precipitation

40 extremes are expected to increase worldwide (IPCC, 2012). To protect 
41 people, properties and infrastructure from damage caused by pluvial

42 flooding, adaptation measures are necessary, especially in urban areas.

43 New ways of managing runoff are increasingly utilised, many focusing on

44 local infiltration and the retention and discharge of water on the surface,

45 which additionally introduces green and blue elements in cities (Wong and

46 Brown, 2009). This approach differs significantly from traditional

47 underground solutions that mainly utilise pipes and sub-surface retention

48 basins. Material demands and construction, operation and disposal

49 processes vary between the two approaches, which leads to different

50 environmental impacts throughout their life cycle. Given the foreseeable

51 extent of CC adaptation measures in the future, their environmental impact

52 is an important parameter. While economic evaluations are frequently

53 carried out, quantitative environmental assessments, including all life cycle

54 stages, are usually not included in the planning process of urban drainage

55 systems. Using life cycle assessment (LCA), the environmental impacts of

56 different adaptation strategies can be quantified. LCA is a standardised

57 approach to evaluating the environmental performance of products and

58 systems (ISO, 2006a), and it is increasingly used in the assessment of

59 water technologies and systems (Loubet et al., 2015). LCA methods are

60 also starting to gain attention in the sub-domain of stormwater

61 management (SWM). A review of existing literature in LCAs of SWM

62 shows a limited number of publications, and the scope is rather

63 inconsistent across studies (Table 1). Urban water systems are complex 
64 and serve various purposes. SWM has to meet multiple targets regarding

65 environmental quality, flood safety and liveability. The clear definition and

66 separation of the elementary (primary) function, and additional

67 (secondary) functions, is crucial in comparative LCA. All alternatives have

68 to provide the same primary function, as defined and quantified in the

69 functional unit, to allow a comparison of environmental impacts. Various

70 approaches employed to define the functional unit have been chosen in

71 previous research. Some researchers define only a specific area, and not

72 the actual service provided, as the functional unit (Flynn and Traver, 2013;

73 Spatari et al., 2011). De Sousa et al. (2012) define a drainage area as the

74 functional unit and implicitly state the function, which in this case is the

75 reduction of annual combined sewer overflow volume. Other researchers

76 define the management of a water volume as the functional unit. This

77 volume is often defined as the runoff from a specific area during a design

78 event (Andrew and Vesely, 2008; Wang et al., 2013) or as a standard

79 volume, for example one cubic meter (Petit-Boix et al., 2015). Secondary

80 functions, for example recreational benefits, are not explicitly stated in any

81 of the reviewed studies. Water quality parameters are considered by

82 various researchers (Clauson-Kaas et al., 2012; Kosareo and Ries, 2007;

83 Taylor and Barrett, 2008), for example by including information regarding

84 treatment efficiencies in the study, without directly relating it to LCA

85 results. Water quality and removal efficiency requirements are included in 
86 the functional unit only by Andrew and Vesely (2008) and O'Sullivan et al. 87 (2015).

88 Differences in the functional unit, leading to problems when 89 comparing alternatives, have been dealt with differently in previous 90 research. Spatari et al. (2011), for instance, account for differences in 91 runoff reduction by crediting the system with savings due to a reduced 92 wastewater treatment (WWT) demand, while Taylor and Barrett (2008) 93 normalise pollutant removal efficiency of each alternative in incorporating 94 differences in water quality. Wang et al. (2013) compare systems which 95 are dimensioned for different design events, by crediting the positive 96 impacts of reduced system capacity requirements. A territorial approach to 97 handling different functionalities is introduced by Loiseau et al. (2013) and 98 adapted to urban water systems by Loubet et al. (2015): An area is 99 defined as the reference flow, which is equal for all the studied 100 alternatives, from which individual functions are derived for different land 101 use scenarios. Results are provided both in the form of environmental 102 impacts and land use functions, which are only partly assessed 103 qualitatively. This allows one to assess alternatives that do not have the 104 same function, which is otherwise not possible in LCA (ISO, 2006b). 105 However, it only permits qualitative and no consistent quantitative 106 comparison.

Apart from differences in the methodological approach, previous 108 research also covers a diverse range of alternatives. Most researchers 
109 include a comparison between multi-functional, green infrastructure

110 approaches and traditional SWM. Some focus on single technologies or

111 installations, e.g. green roofs (Chenani et al., 2015; Kosareo and Ries,

112 2007), rain gardens or sand filters (Andrew and Vesely, 2008). A more

113 comprehensive approach is chosen by De Sousa et al. (2012), who

114 assess the environmental impacts of a combination of different elements

115 to reduce combined sewer overflows, and Spatari et al. (2011), who

116 evaluate the SWM system of a neighbourhood block. From an urban

117 hydrologic viewpoint, it can be problematic to narrow the scope to single

118 installations, because catchments are interconnected. An inflow in one

119 area depends on the characteristics of upstream areas, such as

120 imperviousness and detention and retention capacity. Previous studies

121 have not assessed a CC adaptation strategy that is designed to protect

122 people and assets from more severe rainfall events, and environmental

123 impacts of single elements are only a fraction of the impacts that arise

124 when flood protection targets have to be met. Only with a comprehensive

125 solution, combining various elements over whole catchments, can this

126 goal be achieved. In the following, we present a novel method to analyse

127 and evaluate the environmental performance of CC adaptation strategies

128 for urban areas.

\section{TABLE 1}

The reality of rainfall with large variations in intensity, duration and

131 event frequency is not taken into account in any of the reviewed papers. It 
132 is neither included in the functional unit definition nor incorporated in the

133 analysis of the results. Different rainfall events, ranging from small to

134 extreme, require different solutions and elements; for example, retention

135 basins are usually designed for a 10-year event in Denmark, and they will

136 not be fully utilised in the case of smaller events or provide sufficient

137 capacities to store runoff from larger events. This consequently leads to

138 different environmental impacts that arise from managing different

139 fractions of rainfall. By analysing this coherency, LCA can actively support

140 decision-making during the design phase and help to communicate

141 different stakeholder perspectives and priorities.

142 The aim of this paper is to address the limitations identified in previous

143 research by answering the following questions:

144 - How can the functions of CC adaptation strategies be defined to take

145 into account all relevant elements and thus ensure comparability

146 between alternatives?

147 - What are sources of uncertainty, and how do they influence the life $148 \quad$ cycle impacts of CC strategies?

149 - How do different flood protection goals and system capacities 150 contribute to total environmental impacts?

151 - In terms of environmental impacts, how do strategies managing 152 stormwater locally and above surface perform compared to traditional 153 solutions? 


\section{Methods and data}

156 The approach developed to meet the stated objectives was tested using

157 the Nørrebro catchment in Copenhagen, Denmark (Fig. 1). In adapting to

158 climatic change, cloudburst management plans (CMP) have been

159 developed for the whole city of Copenhagen (The City of Copenhagen,

160 2015a). These plans, which are specified for seven sub-catchments, utilise

161 green infrastructure and local retention as key elements in the

162 management of stormwater, which are implemented by redesigning parks

163 and roads. They are complemented by routing on the surface as well as

164 underground pipes to meet flood safety requirements. In addition, large

165 areas in parks are lowered and used, e.g. for sports, during dry periods,

166 but they can retain water during extreme events. The system is designed

167 to handle all additional runoff, which is expected due to CC until 2110,

168 while the current runoff is managed in the existing combined sewer

169 system. To benchmark the CMP for Nørrebro (HOFOR et al., 2013), an

170 alternative, where green and blue elements are replaced by underground

171 pipes and basins, is assessed. In this sub-surface alternative (SSA), it is

172 assumed that the water is routed via a combined sewer system and

173 treated in an existing wastewater treatment plant (WWTP), before being

174 discharged into the harbour. In extreme events, the runoff is not or only

175 partially cleaned before discharge. 


\subsection{Assessment methodology}

178 The suggested methodology is in accordance with the four steps defined

179 in ISO (2006a), namely goal and scope definition, inventory analysis,

180 impact assessment and results interpretation. The impact assessment is

181 performed using EASETECH, which focuses on material flow modelling

182 and allows a simple set-up of different scenarios (Clavreul et al., 2014).

183 The processes are modelled using the widely used ecoinvent database

184 (Weidema et al., 2013). The International Reference Life Cycle Data

185 System (ILCD) recommended method is used for the impact assessment, 186 and combines methods to assess 16 different impact categories

187 (European Commission, 2010a). Thirteen of these are implemented in 188 EASETECH. The results are presented at midpoint level and are 189 normalised using factors developed in the PROSUITE project (European 190 Commission, 2010b). Furthermore, characterised impacts, which are 191 impact indicator scores with individual units, are aggregated and 192 expressed in person equivalents (PE). This normalisation relates the 193 impact to the average impact per person per year in Europe. The actual 194 effects on endpoint level to humans and ecosystems, such as a decrease 195 in biodiversity or an increase in diseases, are specified in the ILCD 196 handbook (European Commission, 2011). 


\subsection{Goal and scope definition}

198 The functional unit, which is equal for both alternatives, is the 199 management of all additional runoff expected due to CC in a catchment 200 area of $2.6 \mathrm{~km}^{2}$, while meeting well-defined flood safety requirements, for 201 the next 100 years. The amount of water handled in both alternatives is 202 the expected additional runoff due to climatic change, which is calculated 203 using delta changes proposed for Denmark by Arnbjerg-Nielsen (2012). 204 The safety levels are directly linked to the Three Points Approach (3PA) 205 introduced by Fratini et al. (2012). The 3PA divides all rainfall events into 206 three different domains based on their return period (RP): A) the everyday 207 domain with an RP up to 0.2 years; (B) the design domain with an RP up 208 to 10 years and (C) the extreme domain with an RP up to 100 years 209 (Sørup et al., 2016). The corresponding flood safety levels are specified in 210 Table 2, as well as the different strategies utilised in the CMP and the SSA 211 to meet these targets. The combination of all elements constitutes the 212 reference flow for the LCA, which differs between the two alternatives.

\section{TABLE 2}

$214 \quad$ Runoff from different rain events flows through the system along 215 different paths (Fig. 2). Runoff from domain A events is not retained but 216 infiltrated (CMP) or discharged to the WWTP (SSA). Based on the 217 planning documents, it is assumed that all domain A runoff can be handled 218 in a $7330 \mathrm{~m}^{2}$ green area implemented in areas currently used as roads. 
219 This is done by reducing the number of lanes or by narrowing existing 220 streets and sidewalks. Plants potentially have beneficial local effects, e.g. 221 air pollutant removal and carbon storage. However, as newly implemented 222 green areas cover less than $1 \%$ of the total catchment area, these 223 potential benefits from plants are not expected to affect the environmental 224 impacts significantly. Domain B runoff is discharged into pipes and 225 channels and retained in retention volumes in parks and roads in the 226 CMP. Assumptions are necessary regarding the ratio of water that will be 227 discharged via pipes or channels and then retained or discharged directly. 228 In the SSA, it is assumed that all domain B runoff is temporarily stored in 229 retention basins and partly treated at the WWTP $(25 \%)$ or discharged 230 directly $(75 \%)$ via pipes. During domain C events, water will be on the 231 surface in both alternatives, before discharge into a lake (CMP) or a 232 harbour (SSA). The runoff is not treated in the SSA, while it is still partly 233 purified by filtration in drainage layers in the CMP.

\section{FIGURE 2}

Different approaches to including water quality in an assessment

236 can be found in literature, but no standard approach exists at the moment.

237 Water quality parameters are not considered herein, and it is assumed 238 that the same requirements are met in both alternatives, in that runoff is 239 sufficiently cleaned by either infiltration (CMP) or treatment in a traditional 240 WWTP (SSA). Additional functions not directly related to SWM could be 241 defined, e.g. adding recreational value by increasing green areas. If these 
242 functions are included as primary functions, they have to be provided by 243 all alternatives, which would have to be ensured through system 244 expansion (European Commission, 2010a). In this example, this would 245 mean that the same amount of additional green areas would have to be 246 constructed in the SSA, as in the CMP. Since that option is not considered 247 in the planning phase (and indeed is not feasible), the analysis is carried 248 out by assuming that recreational value is a secondary function. It is only 249 provided by the CMP, and is therefore not assessed to ensure 250 comparability with the SSA.

251 All life cycle stages in the two systems are considered: material 252 production and manufacturing, transport to site, construction and 253 operation. Decommissioning and disposal are included to ensure 254 comparability between the alternatives, even though a partial reuse or 255 transformation is more likely than a complete decommissioning. Some 256 processes occur identically in both alternatives, and thus they can be 257 excluded from the comparison; for instance, the maintenance 258 requirements of redesigned park areas (CMP) and park areas in current 259 state (SSA)s are assumed to be equal, and no new park areas are 260 implemented in either alternative. The operation and maintenance of parks 261 is therefore not part of the assessment. Other processes are not included 262 because only a minor fraction would be allocated to the assessed system. 263 Runoff from Nørrebro is treated in the Lynetten WWTP in the SSA which 264 has a catchment area of $76 \mathrm{~km}^{2}$, i.e. 30 times the size of the Nørrebro 
265 catchment (Lynettefællesskabet, 2015); consequently, the construction

266 and end of life of this WWTP are not included. All processes included in 267 the modelling of the two systems are listed in Table 3. The temporal scope 268 of the LCA covers the planning period of 100 years. TABLE 3

\subsection{Uncertainty}

271 Following Huijbregts (1998), uncertainties in LCA are divided into three 272 categories: parameter uncertainty, uncertainty from model choices and 273 model uncertainty.

\subsubsection{Parameter uncertainty}

275 Parameter uncertainty describes uncertainty in data input into the life cycle 276 inventory of the assessment, resulting, for example, from a lack of data or 277 limited representability. The uncertainty of central parameters is tested for 278 their sensitivity by varying the following inputs (Table 4):

279 - Pipe construction: a great deal of variety can be found in the literature 280 regarding the construction demands for laying pipes. In the baseline 281 scenario, only excavation work is included in the inventory, as done by 282 several researchers (Andrew and Vesely, 2008; Flynn and Traver, 283 2013; O'Sullivan et al., 2015). To test this simplification, an estimate of $28475 \mathrm{~L}$ diesel per metre of pipe is used in the model. This is based on 
285 measured data from a construction site in Denmark with comparable 286 characteristics. It includes fuel consumption for all required machinery, 287 e.g. soil compressors, and the transportation of soil to treatment 288 facilities.

289 - End-of-life pipes: pipes are usually not excavated when no longer 290 needed, in order to avoid disruptions due to large construction sites. To 291 prevent collapse, they are filled with thermo beton, which is a lot less 292 dense than normal concrete. This technology is assessed in the 293 baseline scenario, and only small polyethylene pipes are excavated 294 and recycled. Since the decommissioning would take place in 100 295 years' time and the actual processes can only be guessed, an 296 alternative approach is tested in which concrete pipes are also 297 excavated and treated.

298 - Reuse of stones (only CMP): some paved areas in parks, e.g. paths, 299 have to be decommissioned during reconstruction, whereby areas are 300 lowered and drainage layers are installed. It is assumed in the baseline 301 scenario that all paved areas can be reinstalled using decommissioned 302 material, and no additional stones have to be produced and 303 transported to the area. In the uncertainty assessment, a reduced 304 reuse rate of $50 \%$ is tested.

305 - Maintenance of green areas (only CMP): in the baseline scenario, only 306 mowing and the disposal of grass cuttings are considered in the 307 operation phase. The frequency is assumed to be 26 times per year, 
308 which is an average of higher demands in summer and lower demands

309 in winter. The alternative scenario includes a transport demand of 5

310 tons $/ \mathrm{km}$ for every mowing.

311 - Road materials (only SSA): where there are channels in the CMP, it is 312 assumed that conventional roads are maintained in the SSA. A 313 possible reduction in road material demand by $20 \%$ is assessed, which 314 could be achieved with a change in road design.

315 Another type of uncertainty important in the case study is caused by 316 "structural" uncertainty and arises from the choice of boundary conditions 317 for the assessment:

318 - The CC adaptation plan for Nørrebro is in the relatively early planning 319 stage. The system design is currently not specified in detail, and 320 numerous options to implement the different elements are possible. 321 For example, the channels can be implemented using either concrete 322 walls or planted surfaces. This choice is tested with a simplified "green" 323 channel approach, assuming only grass and no other plants on the 324 surface, to benchmark against the baseline scenario with concrete 325 surfaces.

326 - The SSA is designed to economically benchmark the CMP. It could be 327 optimised if surrounding catchments and other possible discharge 328 paths were taken into account. For example, the SSA suggests 14 sub329 surface basins, ranging in size between $227 \mathrm{~m}^{3}$ and $60,000 \mathrm{~m}^{3}$, which 330 would not realistically be constructed in a densely populated area like 
331 Nørrebro. A simple option to improve the system by introducing only

332 one basin is therefore tested.

333 TABLE 4

334 Additional parameter uncertainty stems from lack of knowledge in 335 particular about the future operation of the system:

336 - The assessment has a temporal scope of 100 years, which makes 337 assumptions regarding future operation and disposal processes 338 necessary. In the assessment, it is assumed that currently available 339 processes will still be used in the year 2110. Also, the construction 340 phase of all elements is expected to take place in the coming decades, 341 which is not taken into account in the assessment. The inventory is 342 based on the simplified notion that the plans are fully implemented at 343 the beginning of the planning period.

344 - "Green" SWM is relatively new in Denmark, and only limited measured 345 data are available for the maintenance and renewal processes. 346 Assumptions are made based on expert interviews and handbooks 347 developed by the Copenhagen Municipality (e.g., Københavns 348 Kommune, 2011). Measured data could decrease uncertainty, but they 349 are currently not available.

350 Not only is the operation of the system in the future uncertain, but also its 351 performance under changing conditions. Water systems are vulnerable 352 towards climate and socio-economic changes, which cannot be predicted 353 with certainty (Lempert, 2013). However, the optimisation of the assessed 
354 alternatives regarding possible future scenarios does not lie within the

355 scope of this paper and the future performance is therefore not assessed.

357 Uncertainty from model choices generally describes potential inaccuracies

358 resulting from choices made throughout the whole assessment process,

359 from the definition of the functional unit to the choice of modelled 360 processes. Huijbregts (1998) proposes standardising approaches and 361 methods as one possible option to reduce this type of uncertainty, which is 362 done here by following international standards (ISO, 2006a, 2006b). Model 363 uncertainty describes uncertainty inherent in the model due to, for 364 example, spatial and temporal aggregation or characterisation factors 365 used to transfer emissions to impacts. Limitations due to model 366 uncertainty lead to choices, which is why uncertainty from model choices 367 and model uncertainty are described conjointly in this section.

There are known shortcomings and limitations in the impact 369 assessment phase of LCA. Laurent and Hauschild (2015), for instance, 370 identify problems in normalisation references arising from the inventory, 371 characterisation factors and incomplete coverage of environmental flows. 372 This uncertainty is especially high for toxicity categories. Therefore, results 373 in the toxicity categories (carcinogenic and non-carcinogenic human 374 toxicity and ecotoxicity) are not presented in this paper, as it is assumed 375 they do not reflect the actual impacts. Resource depletion relative to global 
376 reserves is not included, as impacts resulting from the depletion of metals

377 are likely to be overestimated, while impacts from the use of mineral

378 resources are underestimated (Rørbech et al., 2014). The stratospheric

379 ozone depletion impacts are not discussed, as they most likely reflect 380 inaccuracies in the applied process data, since all important ozone381 depleting gases were abandoned in 1996. Consequently, six categories 382 are left out, as uncertainties are identified as unacceptably high. This 383 leaves eight impact categories within the ILCD recommended impact 384 assessment method that are included in the discussion.

385 All impacts are calculated solely from the processes illustrated in 386 Table 3. Processes arising from the discharge of polluted runoff in the 387 system, such as accumulation of substances in the soil or discharge into 388 freshwater bodies, are not considered. Further research is necessary to 389 include these local impacts in the assessment.

\section{$390 \quad 2.5$ Allocation of impacts}

391 To meet the different defined flood safety levels, specific elements are 392 utilised. The overall impacts of the system can therefore be allocated to 393 different safety levels. This can be useful when communicating with 394 different stakeholders, or for optimisation during the design phase. Two 395 allocation schemes are tested, one volume-based and one importance396 based (Table 5). 
Volume-based allocation builds on the flow of runoff from the

398 different domains throughout the system (Fig. 2). Domain A events 399 contribute $75 \%$ to the total annual runoff, $25 \%$ stem from domain B and $4001 \%$ from domain $\mathrm{C}$ events (Sørup et al., 2016). The quantities of water that 401 pass through the single elements are analysed and based on these, the 402 impacts are allocated to the different domains. If an element, for example, 403 only handles domain A runoff, all impacts arising over the life cycle of this 404 element are allocated to domain A. If several domains are managed in an 405 element, the impacts are allocated based on the fraction of the total water 406 volume handled in the element that is contributed by each domain. For 407 instance, $93 \%$ of the water treated at the WWTP stems from domain A 408 events, and only $7 \%$ from domain B events, which directly translates to 409 allocation factors.

410 The other tested allocation scheme is based on a rating of the 411 importance of single flood safety targets, i.e. handling single domains. 412 Stakeholders might value the targets differently: while planners often focus 413 on the design domain (B), people living in flood-prone areas will value 414 protection against extreme events (C) higher, and utilities will try to reduce 415 the flow of lightly polluted everyday runoff (A) through the WWTP. Herein, 416 it is assumed that all flood protection targets are equally important, which 417 means if an element handles runoff from different domains, the impacts 418 will be allocated equally to all domains. If an element handles only runoff 419 from one domain, all impacts will be allocated to that domain (Table 5). 
Some impacts cannot be allocated in both allocation schemes, 422 since they do not arise from processes directly contributing to flood safety.

423 They are caused by necessary by-processes, e.g. for decommissioning of 424 park inventory before lowering. Other impacts cannot be allocated due to 425 the comparative nature of the assessment; for instance, where channels 426 are implemented in the CMP, conventional roads have to be maintained in 427 the SSA.

428 The choice of allocation scheme depends on the context. While 429 flow-based allocation can advocate designing the system and defining 430 flood safety levels, the importance and cost-based schemes are useful 431 support for communication between stakeholders and the analysis of 432 trade-offs.

\section{$433 \quad 3 . \quad$ Results and discussion}

\subsection{Life Cycle Inventory}

435 Data for the inventory were collected from plans and expert interviews and 436 complemented with information from databases. Since the planning is in 437 the rather early stage, numerous assumptions based on existing literature 438 and expert opinions have been made, upon which the life cycle inventory 439 is built. Some important choices are: 
- Elements have different lifetimes and partly have to be renewed during the assessed time period of 100 years. The resulting material, transport, construction and disposal demands are included in the inventory. Several elements consist of different materials which have varying lifetimes, e.g. roads, where the asphalt, bitumen and gravel layers have different renewal demands (Fachverband Infra, 2016).

- To model WWT, only electricity consumption at the plant is considered, as proposed by Godskesen et al. (2013), who develop data specific for Copenhagen.

- No detailed plans for vegetation in the newly implemented green areas have been developed yet. As a simplification, it is assumed that the areas are covered with grass, and trees are planted at a density of $1 / 40 \mathrm{~m}^{2}$. They are assumed to be common lime (Tilia $x$ europaea) (Sæbø et al., 2003), which influences the disposal processes: based on the average height and diameter of the species, the volume of wood for composting at the end of life is calculated.

458 Extensive data collection is carried out for processes in all life cycle stages 459 (Table 3). The inventory specifies energy, fuel, transport and material 460 demands. Table 6 lists the central material demands, and a 461 comprehensive inventory including assumptions is provided in the 462 supporting information. 


\subsection{Impacts of climate change adaptation}

465 The impacts of the CMP vary between 3 and $18 \mathrm{PE} / \mathrm{year}$. The impacts of 466 the SSA are consistently higher in all impact categories, ranging between 46714 and $103 \mathrm{PE} /$ year (Fig. 3). The magnitude of the results seems 468 reasonable considering that 79,000 people live in the administrative area 469 Nørrebro (The City of Copenhagen, 2015b), which is to a large extent 470 covered by the catchment. The impacts of the passive SWM systems only 471 contribute a small fraction of the total impacts that arise in the catchment, 472 which take into account all goods and services, such as transport and 473 energy. For climate change impacts, this translates to approximately $4740.02 \%$ of the average total impacts per person, which is less than 475 Clauson-Kaas et al. (2012) estimate as a contribution of stormwater 476 treatment alone $(0.15 \%-0.5 \%)$. It is difficult to compare the calculated 477 impacts to the results found in the literature, since different methodology 478 and system definitions are used. De Sousa et al. (2012) compare two 479 different SWM alternatives for a catchment area of 784 ha, which is three 480 times the size of the Nørrebro catchment. Assessing the impacts arising 481 from green infrastructure elements, or a retention basin alternative, they 482 found that the implementation of the green infrastructure caused 483 emissions of $20,000 \mathrm{t} \mathrm{CO}_{2}$ eq., that $100,000 \mathrm{t} \mathrm{CO}_{2}$ eq. are caused by the 484 basin. Overall emissions for the CMP are $11,500 \mathrm{t} \mathrm{CO}_{2}$ eq., and $31,200 \mathrm{t}$ 
$485 \mathrm{CO}_{2}$ eq. for the SSA. In both cases, the impacts of the green 486 infrastructure-based system are significantly lower, and a major share of 487 the impacts in all alternatives stems from material production.

488 For both the CMP and the SSA, the category with the highest 489 impacts is depletion of fossil resources (18 PE/year for the CMP, and 103 $490 \mathrm{PE} /$ year for the SSA), mainly caused by the production of concrete, steel 491 and road materials, and the consumption of fuels for construction. For the 492 CMP, the second-highest impacts are caused by a group of categories 493 (climate change and marine and terrestrial eutrophication) with impacts at 494 around $14 \mathrm{PE} / \mathrm{year}$, which mainly stem from fuel combustion in the 495 production of materials like concrete. For the SSA, the second-highest 496 impacts are for climate change (52 PE/year). Across the categories, 497 impacts from the SSA are three to 12 times higher than the impacts from 498 the CMP. The largest difference is observed for freshwater eutrophication. 499 Eutrophication impacts in freshwater are caused by discharges of 500 phosphorus and phosphates, and only emissions from life cycle processes 501 and the WWTP are taken into account. As water quality is defined as a 502 secondary function, no direct discharges from runoff are taken into 503 account. This could possibly increase the eutrophication impacts of the 504 CMP, and so further research is necessary to quantify this indication. 
507 impacts shows that material production contributes most to the total 508 impacts in both alternatives $(42-75 \%$ for the CMP, and $62-96 \%$ in the 509 SSA) (Fig. 4). This is in accordance with (Flynn and Traver, 2013), who 510 assess the impacts of rain gardens. They find that $80 \%$ stem from material 511 production, and only $20 \%$ from construction processes, while other life 512 cycle stages have minor or even positive impacts. In the CMP, concrete 513 production for channels and pipes causes between 75 and up to $99 \%$ of 514 the material production impacts. The channels are implemented on road 515 areas which explains the high contribution of roads in the CMP to the 516 overall impacts $(55-67 \%)$. Parks are the elements with the second517 highest impacts $(10-41 \%)$, with the transport of material for the drainage 518 layers for runoff treatment being the most significant process ( $36-74 \%$ of 519 the park impacts). More than 7,000 t of gravel and 1,500t of clay are 520 assumed to be necessary to construct the drainage layers, and these 521 extend over an area of almost $5,000 \mathrm{~m}^{2}$. It is also assumed that the gravel 522 layer has to be renewed every 25 years, due to the accumulation of 523 pollutants. Positive environmental impacts are caused by recycling pipes 524 made from polyethylene, which reduces the overall impacts by between 12 525 and $21 \%$. Steel used in basins causes most of the impacts to the SSA at the 527 material production stage $(26-79 \%)$, with concrete being the second 528 most causal material $(6-28 \%)$. Also, asphalt and bitumen required for 
529 road renewal in the SSA cause relatively high impacts $(14-69 \%$ of the 530 material production impacts). This leads to high contributions to the total 531 impacts by both roads (16 - 65\%) and basins (28 - 80\%) (Fig. 4). 532 Emissions of carbon dioxide, NOx, sulphur dioxide and phosphate cause 533 high impacts in the different impact categories. They are mainly due to 534 high energy demands for the production process of steel, and in the model 535 it is assumed that this energy is provided by burning coal, gas and oil. The 536 Danish government is aiming to replace these completely with renewable 537 energy sources by 2050 (The Danish Government, 2011). This change 538 would lead to reductions in impacts, e.g. for fossil resource depletion due 539 to electricity consumption for WWT.

540 Operation contributes insignificantly in both alternatives and across 541 impact categories. This is due to the fact that even though the systems 542 have to be maintained over 100 years, the attributed resource and energy 543 demands are small compared to the initial implementation stage, where 544 large amounts of materials and intensive construction works are 545 necessary. Decommissioning and disposal only take place once, and 546 since a lot of the waste can be composted (grass and tree clippings) or 547 landfilled (gravel and soil), these processes also only contribute 548 marginally. 


\subsection{Uncertainty}

551

\subsubsection{Sensitivity analysis}

552 Parameters that are characterised by high uncertainty are tested for their 553 influence on the results in a sensitivity analysis. Impacts from alternative 554 scenarios with significant influence are illustrated in Fig. 5. The parameter 555 showing the largest effect in both scenarios is the pipe construction 556 process: taking into account not only excavation, but also other machinery 557 use based on an expert estimate, increases total impacts across the 558 categories by $1 \%$ to $68 \%$ for the CMP and by $<1$ to $18 \%$ for the SSA (Fig. 559 5). The terrestrial eutrophication impacts are most affected, with NOx 560 emissions from fuel combustion causing the largest share of the impacts.

561 The high sensitivity shows the importance of taking into account 562 supporting processes and using case-specific data. Depending on the size 563 and depth of the pipe, as well as the characteristics of the area (existing 564 structures and restrictions), the required machinery and processes for 565 laying pipes vary widely. These data can only be collected with certainty 566 during the implementation phase of the project.

$567 \quad$ Opposed to the construction phase, the end-of-life of pipes does 568 not contribute significantly. The overall impacts only vary by up to $3 \%$ for 569 the CMP, and less than $1 \%$ for the SSA, if the concrete pipes are 570 excavated and treated instead of being filled with thermo beton. Also, the 571 alternative maintenance scenario, which includes transport of equipment 
572 to the site, does not lead to significant increases in CMP impacts $(<1 \%$ for 573 all impact categories). Assuming a reduced reuse rate of $50 \%$ for stones

574 for paved areas in the CMP increases the overall impacts by 13 to $30 \%$. A

575 reduction in used road materials by $20 \%$ in the SSA lowers the impacts by 5763 to $13 \%$ (Fig. 5). The reuse rate of materials and the demand for road 577 materials are parameters that can be optimised, and they should therefore 578 be taken into consideration throughout the planning of a CC adaptation 579 strategy. However, all tested alternative SSA scenarios have higher 580 impacts than the CMP scenarios. Taking parameter uncertainty into 581 account, therefore, does not change the overall conclusion that the CMP is 582 the environmentally preferable alternative.

\section{FIGURE 5}

\subsubsection{Structural uncertainty}

585 Two different system designs are tested to assess structural 586 uncertainty. For the CMP, a change in design from concrete to "green" 587 channels reduces the impacts by 9 to $27 \%$ (Fig. 6). The assessment of the 588 "green" channel design is simplified, and the impacts could therefore likely 589 be higher, albeit still below the baseline scenario, as the use of concrete 590 causes significant impacts in all life cycle stages: It is energy-intensive to 591 produce, heavy to transport and poses a significant burden at the end of 592 its life. The large differences between alternative channel layouts 593 highlights the possibility of influencing environmental impacts during the 
594 system design and is a strong argument for conducting an LCA to reveal 595 optimisation possibilities and potential trade-offs already in an early stage 596 of the planning, when substantial design choices are yet to be made. 597 Changes in design that reduce the demand for resource- and energy598 intensive materials, i.e. "green" elements that fulfil the same function, will 599 lower the environmental impacts of SWM solutions. This conclusion is in 600 accordance with O'Sullivan et al. (2015), who find that stormwater 601 treatment systems using a lot of concrete have the largest environmental 602 impacts.

603 For the SSA, an improved design alternative incorporating only one 604 basin, instead of 14 , is tested. This leads to a reduction in impacts 605 between 9 and 15\% (Fig. 6). Additionally, for a decreased number of 606 basins, a reduction in retention volume would be environmentally 607 beneficial. It might also be economically favourable to compensate the 608 greater damage that would arise from flooding instead. This option could 609 be considered in the decision-making process. However, the CMP 610 remains the environmentally preferable option, regardless of structural 611 changes in the systems. 


\subsection{Allocation of impacts to rain domains}

614 Using the volume-based allocation scheme, the management of domain B

615 events with return periods between 0.2 and 10 years causes the major 616 share of impacts in both alternatives $(90-95 \%$ for the CMP, and $30-$ $61781 \%$ for the SSA) (Fig. 7). This seems like a logical consequence of the 618 fact that events with a return period of 10 years are usually used to design 619 SWM systems. Domain A runoff has a much larger total annual volume, 620 but it can be handled in smaller systems, i.e. designed to infiltrate instead 621 of discharge, which causes fewer environmental impacts. As it is assumed 622 that all domain A runoff can be handled in the new green areas, the share 623 of impacts of this domain is very small in the CMP $(1-6 \%)$. Other 624 elements, like channels and pipes, are possibly used during domain A 625 events, which would lead to a higher share of impacts allocated to domain 626 A. Only a detailed flow analysis during a later planning stage can reduce 627 the uncertainty of the results based on the volume based allocation.

628 The handling of domain C runoff, which stems from extreme events 629 with a return period greater than 10 years, does not contribute significantly 630 to the overall results $(4-5 \%$ of the CMP, and $\leq 1 \%$ of the SSA) (Fig. 7 ), 631 due to the primary function of the system, which allows $10 \mathrm{~cm}$ of water on 632 the surface during domain $C$ events. This creates a retention space 633 without actually implementing SWM elements. Also, it is assumed that 634 structures designed for domain B events are used during domain C 
635 events, until their capacity is reached and the water "overflows", either into 636 lakes (in the CMP) or a harbour (in the SSA).

637 However, using the importance-based allocation scheme, domain C 638 contributes much more significantly to the impacts of the CMP $(48-49 \%)$, 639 which is equal to the contribution of domain B. It is assumed that all 640 discharge and retention elements of the CMP are both used in cases of 641 domain $B$ and $C$ events. If both domains are valued equally, the impacts 642 have to be distributed uniformly, regardless of the frequency and depth of 643 the events.

644 In the SSA, the share of domain C is still small compared to domain 645 B $(1-3 \%$, and $39-81 \%$ respectively $)$. The increased capacity of the 646 sewer system, by introducing pipes, is assumed to ensure a maximum 647 water level of $10 \mathrm{~cm}$ on the surface during domain $C$ events, and no 648 additional structures like basins are used, which limits the environmental 649 impacts.

650 The share of unallocated impacts not directly linked to the 651 functional unit is quite large for the SSA (16 - 65\%) (Fig. 7). These 652 impacts mainly result from renewed roads, in that where there are 653 channels implemented in the CMP, it is assumed that the traditional road 654 surface has to be maintained in the SSA, which causes renewal, operation 655 and disposal demands. The roads do not handle runoff, though, and their 656 impacts can therefore not be allocated to any of the three domains. These 
657 implicitly required elements causing "hidden" impacts have to be included

658 to ensure comparability between systems. Unallocated impacts arise also 659 in the CMP, due to necessary preparation works, for example in 660 connection with reconstructing parks. They constitute a much smaller 661 fraction of the total impacts than in the SSA $(\leq 1 \%)$.

662 The volume-based allocation shows that even though the plans aim 663 to prevent damage from extreme events, environmental impacts mainly 664 arise from handling smaller events. In the planning processes, especially 665 when defining flood safety targets, this is valuable information. By 666 adjusting both acceptable water levels and the frequency of allowed 667 flooding, environmental impacts can be reduced, but greater damage will 668 occur. By allocating the impacts to rain domains, this trade-off can be 669 quantified and therefore supports a transparent decision-making process. 670 Importance weighting can add more information, if flood safety levels are 671 valued differently. While some plans, as in this case, aim to handle over $67299 \%$ of all rain events, others focus on frequent, small rain events to 673 reduce the load going into the sewer system. Importance based-allocation 674 reflects this prioritisation; for example, if domain $A$ events are the focus of 675 an adaptation plan, it seems acceptable that they will also contribute the 676 main share of the impacts. If, on the other hand, secondary interests 677 cause significant environmental impacts, there is potential for optimisation 678 in the planning phase. The difference in results between the allocation 679 schemes shows a discrepancy between anticipated system design and 
680 actual system function: The main goal is protection against extreme

681 events, which is mirrored in the weighting-based allocation. However, 682 implemented elements are mainly used in the case of events with a return 683 period of up to 10 years, and not during more severe events.

684 FIGURE 7

685 4. Conclusion

686 LCA of CC adaptation strategies provides quantitative information 687 regarding the environmental impacts of different adaptation options. By 688 defining the primary function as providing flood safety targets, the 689 comparability of the alternatives is ensured. However, defining a water 690 volume or catchment area as the functional unit does not allow the same 691 conclusions. This novel approach to defining the system and scope allows 692 conclusions on a system level, in contrast to previous research focused on 693 single installations or only parts of SWM systems, instead of 694 comprehensive strategies. The focus of previous research is often on $\mathrm{CO}_{2}$ 695 emissions and energy demands, but analysing eight impact categories 696 gives a broader picture of occurring environmental impacts. Using the 697 Three Points Approach to differentiate between rainfall domains allows a 698 clear definition of the functional unit. As such, we found that:

- Allocating environmental impacts to different flood safety levels 700 provides valuable information during the planning process. It allows for 
701 analysing the contribution to the overall impacts of managing the

702 different domains, which can be used to optimise systems and define

703 design criteria. It also facilitates communication between stakeholders

704 with different priorities and allows one to quantify trade-offs between

705 environmental sustainability and flood safety.

706 - In order to optimise the environmental performance of SWM systems,

707 LCAs are ideally conducted at different stages of the planning process,

708 in order to influence the design process already in an early stage.

709 Uncertainty has to be assessed systematically, in order to be able to

710 draw conclusions. Parameter and structural uncertainty is high in early

711 planning stages, and a sensitivity analysis allows one to identify

712 environmentally preferable design alternatives while taking

713 uncertainties into account.

714 - The case study shows that the Cloudburst Management Plan, which

715 mainly uses green infrastructure elements, has 71 to $92 \%$ fewer

716 environmental impacts than a sub-surface alternative (3 to $18 \mathrm{PE} /$ year

717 for the CMP, and 14 to $103 \mathrm{PE} /$ year for the SSA). Material production

718 processes cause the largest share of overall impacts, with concrete,

719 steel and road materials contributing most in this regard. Handling of

720 events with a return period between 0.2 and 10 years contributes most

721 to the impacts. Small events (return period up to 0.2 years) contribute

722 the least, regardless of the allocation scheme. Analysing uncertainty

723 highlights the importance of using site-specific data. 


\section{Acknowledgements}

The Ministry of Science, Technology and Innovation in Denmark and VCS Denmark, HOFOR and Aarhus Vand funded the Industrial PhD project in which this research was carried out. Margit Lund Christensen,

729 Nis Fink and Jesper Rasmussen are gratefully acknowledged for providing 730 data for the test case. The authors also thank Christian Ammitsøe and 731 Hjalte Jomo Danielsen Sørup for improving the draft of the paper, and 732 Anders Damgaard for the modelling support.

\section{References}

734

735

736

737

738

739

740

741

742

743

744

745

746

747

748

749

Andrew, R.M., Vesely, É.T., 2008. Life-cycle energy and CO2 analysis of stormwater treatment devices. Water Sci. Technol. 58, 985-993. doi:10.2166/wst.2008.455

Arnbjerg-Nielsen, K., 2012. Quantification of climate change effects on extreme precipitation used for high resolution hydrologic design. Urban Water J. 9, 57-65. doi:10.1080/1573062X.2011.630091

Chenani, S.B., Lehvävirta, S., Häkkinen, T., 2015. Life cycle assessment of layers of green roofs. J. Clean. Prod. 90, 153-162. doi:10.1016/j.jclepro.2014.11.070

Clauson-Kaas, J., Sørensen, B.L., Dalgaard, O.G., Sharma, A.K., Johansen, N.B., Rindel, K., Andersen, H.K., 2012. Carbon footprint and life cycle assessment of centralised and decentralised handling of wastewater during rain. J. Water Clim. Chang. 3, 266-275. doi:10.2166/wcc.2012.036

Clavreul, J., Baumeister, H., Christensen, T.H., Damgaard, A., 2014. An environmental assessment system for environmental technologies. 
751

752

753

754

755

756

757

758

759

760

761

762

763

764

765

766

767

768

769

770

771

772

773

774

775

776

777

778

779

780

781

782

783

784

785

786

787

788

789

De Sousa, M.R.C., Montalto, F. a., Spatari, S., 2012. Using Life Cycle Assessment to Evaluate Green and Grey Combined Sewer Overflow Control Strategies. J. Ind. Ecol. 16, 901-913. doi:0.1111/j.15309290.2012.00534.x

European Commission, 2011. - Joint Research Centre - Institute for Environment and Sustainability: International Reference Life Cycle Data System (ILCD) Handbook - Recommendations for Life Cycle Impact Assessment in the European context. EUR 24571 EN. Publications Office of the European Union, Luxemburg. doi: $10.278 / 33030$

European Commission, 2010a. - Joint Research Center - Institute for Environment and Sustainability: International Reference Life Cycle Data System (ILCD) Handbook - General guide for Life Cycle Assessment - Detailed guidance, Constraints. Publications Office of the European Union, Luxembourg. doi:10.2788/38479

European Commission, 2010b. Final Report Summary - PROSUITE (Development and application of standardized methodology for the PROspective SUstalnability assessment of TEchnologies). Project reference: 227078.

Fachverband Infra, 2016. Life expectancy of roads (Lebensdauer von Strassen) [WWW Document]. URL http://www.wir-arbeiten-fuersie.ch/de/49_strassen/64_strassennetz/136_lebensdauer_von_strass en.pdf (accessed 5.25.16).

Flynn, K.M., Traver, R.G., 2013. Green infrastructure life cycle assessment: A bio-infiltration case study. Ecol. Eng. 55, 9-22. doi:10.1016/j.ecoleng.2013.01.004

Fratini, C.F., Geldof, G.D., Kluck, J., Mikkelsen, P.S., 2012. Three Points Approach (3PA) for urban flood risk management: A tool to support climate change adaptation through transdisciplinarity and multifunctionality. Urban Water J. 9:5, 317-331. doi:10.1080/1573062X.2012.668913

Godskesen, B., Hauschild, M., Rygaard, M., Zambrano, K., Albrechtsen, H.J., 2013. Life-cycle and freshwater withdrawal impact assessment of water supply technologies. Water Res. 47, 2363-2374. doi:10.1016/j.watres.2013.02.005

HOFOR, The City of Copenhagen, Rambøll, 2013. Concretion of the Cloudburst Management Plan for the Nørrebro catchment (Konkretisering af Skybrudsplanen for Nørrebro-Oplandet). Copenhagen, Denmark. 
790

791

792

793

794

795

796

797

798

799

800

801

802

803

804

805

806

807

808

809

810

811

812

813

814

815

816

817

818

819

820

821

822

823

824

825

826

827

Huijbregts, M., 1998. Application of uncertainty and variability in LCA. Int. J. Life Cycle Assess. 3, 273-280. doi:10.1007/BF02979835

IPCC, 2014. Climate Change 2014: Synthesis Report. Geneva, Switzerland.

IPCC, 2012. Managing the Risks of Extreme Events and Disasters to Advance Climate Change Adaptation. A Special Report of Working Groups I and II of the Intergovernmental Panel on Climate Change. Cambridge University Press, Cambridge, UK, and New York, NY, USA.

ISO, 2006a. Environmental Management - Life Cycle Assessment Principles and framework - ISO 14044, ISO 14044:2006. Brussels, Belgium.

ISO, 2006b. Environmental Management - Life Cycle Assessment Requirements and guidelines - ISO 14044, ISO 14040:2006. Brussels, Belgium.

Kosareo, L., Ries, R., 2007. Comparative environmental life cycle assessment of green roofs. Build. Environ. 42, 2606-2613. doi:10.1016/j.buildenv.2006.06.019

Laurent, A., Hauschild, M.Z., 2015. Normalisation, in: Hauschild, M.Z., Huijbregts, M.A.J. (Eds.), Life Cycle Impact Assessment. LCA Compendium - The Complete World of Life Cycle Assessment. Springer Press, pp. 271-300. doi:10.1007/978-94-017-9744-3_14

Lempert, R., 2013. Scenarios that illuminate vulnerabilities and robust responses. Clim. Change 117, 627-646. doi:10.1007/s10584-0120574-6

Loiseau, E., Roux, P., Junqua, G., Maurel, P., Bellon-Maurel, V., 2013. Adapting the LCA framework to environmental assessment in land planning. Int. J. Life Cycle Assess. 18, 1533-1548. doi:10.1007/s11367-013-0588-y

Loubet, P., Roux, P., Bellon-Maurel, V., 2015. WaLA, a versatile model for the life cycle assessment of urban water systems: formalism and framework for a modular approach. Water Res. Submitted. doi:10.1016/j.watres.2015.09.034

Lynettefællesskabet, 2015. Lynetten fact sheet (Lynetten i tal) [WWW Document]. URL http://www.lyn-is.dk/Lynetten/Lynetten_i_tal.aspx (accessed 5.8.15).

O'Sullivan, A.D., Wicke, D., Hengen, T.J., Sieverding, H.L., Stone, J.J., 2015. Life Cycle Assessment modelling of stormwater treatment 
846

847

848

849

850

851

852

853

854

855

856

857

858

859 860

861

862

863

864

865

systems. J. Environ. Manage. 149, 236-244. doi:10.1016/j.jenvman.2014.10.025

Petit-Boix, A., Sevigné, E., La, R.-G., Barbassa, A., Josa, A., Rieradevall, J., Gabarrell, X., 2015. Environmental and economic assessment of a pilot stormwater infiltration system for flood prevention in Brazil. Ecol. Eng. 84, 194-201. doi:10.1016/j.ecoleng.2015.09.010

Rørbech, J.T., Vadenbo, C., Hellweg, S., Astrup, T.F., 2014. Impact Assessment of Abiotic Resources in LCA: Quantitative Comparison of Selected Characterization Models. Environ. Sci. Technol. 48, 1107211081. doi:10.1021/es5023976

Sæbø, A., Benedikz, T., Randrup, T.B., 2003. Selection of trees for urban forestry in the Nordic countries. Urban For. Urban Green. 2, 101-114. doi:10.1078/1618-8667-00027

Sørup, H.J.D., Lerer, S.M., Arnbjerg-Nielsen, K., Mikkelsen, P.S., Rygaard, M., 2016. Efficiency of stormwater control measures for combined sewer retrofitting under varying rain conditions: Quantifying the Three Points Approach (3PA). Environ. Sci. Policy 63, 19-26. doi:10.1016/j.envsci.2016.05.010

Spatari, S., Yu, Z., Montalto, F.A., 2011. Life cycle implications of urban green infrastructure. Environ. Pollut. 159, 2174-2179. doi:10.1016/j.envpol.2011.01.015

Taylor, S., Barrett, M., 2008. Assessing Environmental Impact of Storm Water Treatment Controls Through a Carbon Signature, in: 11th International Conference on Urban Drainage, Edinburgh, Scotland, UK, 2008.

The City of Copenhagen, 2015a. Climate Change Adaptation and Investment Statement. Copenhagen, Denmark.

The City of Copenhagen, 2015b. Copenhagen statistics fact sheet (Faktaark fra Københavns Statistik) [WWW Document]. URL http://www.kk.dk/sites/default/files/2015_Befolkningen efter bydele og areal..pdf (accessed 5.20.16).

The City of Copenhagen, 2011. Trenches and swales; Gl method catalogue (Render og grøfter; LAR-metodekatalog).

The Danish Government, 2011. Energy Strategy 2050 - From Coal, Oil and Gas to Green Energy, Danish Energy Agency.

Wang, R., Eckelman, M.J., Zimmerman, J.B., 2013. Consequential environmental and economic life cycle assessment of green and gray stormwater infrastructures for combined sewer systems. Environ. Sci. 
867 Weidema, B.P., Bauer, C., Hischier, R., Mutel, C., Nemecek, T., Reinhard, 868 J., Vadenbo, C.O., Wernet, G., 2013. The ecoinvent database: 869 Overview and methodology, Data quality guideline for the ecoinvent 870 database version 3.

871 Wong, T.H.F., Brown, R.R., 2009. The water sensitive city: Principles for 872 practice. Water Sci. Technol. 60, 673-682. doi:10.2166/wst.2009.436

873

874 
875 Table 1. Study scope of the existing literature on life cycle assessment in

876 stormwater management. Life cycle stage abbreviations: material

877 production $(\mathrm{M})$, construction $(\mathrm{C})$, operation $(\mathrm{O})$, decommissioning and

878 disposal (D), transport (T). ${ }^{*}$ Study does not explicitly define a functional

879 unit.

\begin{tabular}{|c|c|c|c|c|c|c|}
\hline Reference & Region & Functional unit & $\begin{array}{l}\text { Temporal } \\
\text { scope }\end{array}$ & $\begin{array}{l}\text { No. of } \\
\text { alternatives }\end{array}$ & $\begin{array}{l}\text { No. of impact } \\
\text { categories }\end{array}$ & $\begin{array}{l}\text { Life cycle } \\
\text { stages }^{1}\end{array}$ \\
\hline $\begin{array}{l}\text { (Kosareo and } \\
\text { Ries, 2007) }\end{array}$ & Pittsburgh, US & Roof area* & 50 years & 3 & 15 & $\mathrm{O}, \mathrm{D}, \mathrm{T}$ \\
\hline $\begin{array}{c}\text { (De Sousa et al., } \\
\text { 2012) }\end{array}$ & Bronx, US & Area & 50 years & 3 & 1 & $\mathrm{M}, \mathrm{O}, \mathrm{T}$ \\
\hline $\begin{array}{l}\text { (Spatari et al., } \\
\text { 2011) }\end{array}$ & New York City, US & Area & (not specified) & 2 & 2 & $\mathrm{M}, \mathrm{O}, \mathrm{T}$ \\
\hline $\begin{array}{c}\text { (Taylor and } \\
\text { Barrett, 2008) }\end{array}$ & California, US & Area* & 20 years & 7 & 1 & $\mathrm{C}, \mathrm{O}$ \\
\hline $\begin{array}{l}\text { (Wang et al., } \\
\text { 2013) }\end{array}$ & Northeast US & Water volume* & (not specified) & 3 & 2 & $\mathrm{M}, \mathrm{C}, \mathrm{O}, \mathrm{T}$ \\
\hline $\begin{array}{l}\text { (Andrew and } \\
\text { Vesely, 2008) }\end{array}$ & North Shore City, NZ & Water volume & 50 years & 3 & 2 & $\mathrm{M}, \mathrm{C}, \mathrm{O}, \mathrm{D}$ \\
\hline $\begin{array}{c}\text { (Flynn and Traver, } \\
\text { 2013) }\end{array}$ & Villanova, US & Area & 30 years & 1 & 8 & $\mathrm{M}, \mathrm{C}, \mathrm{O}, \mathrm{D}, \mathrm{T}$ \\
\hline $\begin{array}{l}\text { (Clauson-Kaas et } \\
\text { al., 2012) }\end{array}$ & Copenhagen, DK & Water volume & 1 year & 4 & 13 & $M, O, D$ \\
\hline $\begin{array}{l}\text { (Petit-Boix et al., } \\
\text { 2015) }\end{array}$ & Sao Carlos, BR & Water volume & 10 years & 3 & 10 & $\mathrm{M}, \mathrm{C}, \mathrm{D}, \mathrm{T}$ \\
\hline $\begin{array}{l}\text { (O'Sullivan et al., } \\
\text { 2015) }\end{array}$ & NZ & Water volume & 30 years & 3 & 18 & $\mathrm{M}, \mathrm{C}, \mathrm{O}, \mathrm{T}$ \\
\hline
\end{tabular}


881 Table 2. Flood safety levels and reference flows for the different

882 alternatives. The return periods refer to anticipated precipitation amounts

883 for Copenhagen in 2110.

\begin{tabular}{|c|c|}
\hline Flood safety level (for the year 2110) & $\begin{array}{l}\text { Reference flow } \\
\text { Cloudburst Management Plan } \quad \text { Sub-surface alternative }\end{array}$ \\
\hline $\begin{array}{l}\text { Domain A: No water on the surface for events with a } \\
\text { return period up to } 0.2 \text { years }\end{array}$ & Green road elements \\
\hline $\begin{array}{l}\text { Domain B: Water above the surface only in designated } \\
\text { areas for events with a return period up to } 10 \text { years }\end{array}$ & $\begin{array}{l}\text { Pipes, channels, retention volumes in } \begin{array}{c}\text { Pipes, underground retention } \\
\text { parks, drainage layers }\end{array} \quad \text { basins, wastewater treatment plant }\end{array}$ \\
\hline $\begin{array}{l}\text { Domain C: A maximum of } 10 \mathrm{~cm} \text { of water on the surface } \\
\text { for events with a return period up to } 100 \text { years }\end{array}$ & $\begin{array}{l}\text { Pipes, channels, retention volumes in } \\
\text { parks, drainage layers }\end{array}$ \\
\hline
\end{tabular}


885 Table 3. Considered processes and lifetimes for the different elements in

886 all life cycle stages of the two alternatives. The detailed inventory is

887 provided in the supporting information. * Components of the elements

888 have varying lifetimes, e.g. grass areas will be completely renewed every

8892 years, while trees only have to be planted once. ${ }^{* *}$ Complete reuse of

890 existing pavement material, and no additional material demands are

891 assumed.

\begin{tabular}{|c|c|c|c|c|c|c|c|c|}
\hline & Element & Alternative & Materials & Transport & $\begin{array}{c}\text { Preparation \& } \\
\text { construction }\end{array}$ & $\begin{array}{l}\text { Operation \& } \\
\text { maintenance }\end{array}$ & $\begin{array}{l}\text { Decommiss. \& } \\
\text { disposal }\end{array}$ & Life time \\
\hline \multirow{3}{*}{ 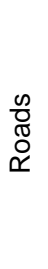 } & Channels & CMP & Concrete & Truck & $\begin{array}{l}\text { Excavation, } \\
\text { soil disposal }\end{array}$ & Cleaning & $\begin{array}{l}\text { Excavation, } \\
\text { treatment }\end{array}$ & 25 years \\
\hline & Green areas & CMP & $\begin{array}{l}\text { Grass seeds, } \\
\text { tree seedlings }\end{array}$ & Truck & $\begin{array}{l}\text { Sowing, } \\
\text { planting }\end{array}$ & $\begin{array}{l}\text { Cutting, } \\
\text { composting }\end{array}$ & $\begin{array}{l}\text { Excavation, } \\
\text { composting }\end{array}$ & $\begin{array}{l}2-100 \\
\text { years }^{*}\end{array}$ \\
\hline & $\begin{array}{l}\text { Renewed } \\
\text { road }\end{array}$ & SSA & $\begin{array}{c}\text { Asphalt, } \\
\text { bitumen, gravel }\end{array}$ & Truck & $\begin{array}{l}\text { Excavation, } \\
\text { soil disposal }\end{array}$ & Cleaning & $\begin{array}{c}\text { Exc., treatment, } \\
\text { landfilling }\end{array}$ & 25 years \\
\hline \multirow{3}{*}{$\begin{array}{l}\frac{n}{\sqrt{v}} \\
\frac{0}{0}\end{array}$} & $\begin{array}{l}\text { Lowered } \\
\text { areas }\end{array}$ & CMP & - & & $\begin{array}{l}\text { Excavation, } \\
\text { soil disposal }\end{array}$ & - & - & - \\
\hline & $\begin{array}{l}\text { Drainage } \\
\text { layers }\end{array}$ & CMP & Clay \& gra & & Excavation & - & $\begin{array}{l}\text { Excavation, } \\
\text { landfilling }\end{array}$ & $\begin{array}{l}25-50 \\
\text { years }^{*}\end{array}$ \\
\hline & Paved areas & CMP & & - & $\begin{array}{l}\text { Excavation, } \\
\text { soil disposal }\end{array}$ & - & - & $\begin{array}{l}30-95 \\
\text { years }^{*}\end{array}$ \\
\hline \multirow{2}{*}{$\begin{array}{l}\mathscr{ఖ} \\
\stackrel{\varrho}{2}\end{array}$} & $\begin{array}{l}\text { Concrete } \\
\text { pipes }\end{array}$ & CMP, SSA & Con & Truck & $\begin{array}{l}\text { Excavation, } \\
\text { soil disposal }\end{array}$ & $\begin{array}{l}\text { Cleaning, } \\
\text { inspection }\end{array}$ & $\begin{array}{l}\text { Filling with } \\
\text { thermo beton }\end{array}$ & 100 years \\
\hline & $\begin{array}{l}\text { Polyethylene } \\
\text { pipes }\end{array}$ & CMP, SSA & olyethylene & Truck & $\begin{array}{l}\text { Excavation, } \\
\text { soil disposal }\end{array}$ & $\begin{array}{l}\text { Cleaning, } \\
\text { inspection }\end{array}$ & $\begin{array}{l}\text { Excavation, } \\
\text { recycling }\end{array}$ & 100 years \\
\hline $\begin{array}{l}\stackrel{\infty}{\bar{c}} \\
\mathbb{\mathscr { T }} \\
\infty\end{array}$ & $\begin{array}{l}\text { Underground } \\
\text { retention } \\
\text { basins }\end{array}$ & SSA & $\begin{array}{l}\text { Reinforced } \\
\text { concrete }\end{array}$ & Truck & $\begin{array}{l}\text { Excavation, } \\
\text { soil disposal }\end{array}$ & - & $\begin{array}{l}\text { Excavation, } \\
\text { treatment }\end{array}$ & 100 years \\
\hline$\sum_{3}^{0}$ & $\begin{array}{l}\text { Wastewater } \\
\text { treatment }\end{array}$ & SSA & - & - & - & $\begin{array}{c}\text { Electricity } \\
\text { consumption }\end{array}$ & - & - \\
\hline
\end{tabular}


893 Table 4. Approach for testing the importance of parameter uncertainty.

\begin{tabular}{|c|c|c|}
\hline Parameter & Baseline approach & Alternative approach \\
\hline Pipe construction & Only excavation works & Excavation, transport and other processes \\
\hline End-of-life concrete pipes & Filling of pipes with thermo beton & Excavation and treatment \\
\hline Reuse of stones & $100 \%$ reuse & $50 \%$ reuse \\
\hline Maintenance of green areas & Only mowing and disposal of clippings & Mowing, disposal of clippings and transport \\
\hline Road materials & $10 \mathrm{~cm}$ asphalt, $10 \mathrm{~cm}$ bitumen, $55 \mathrm{~cm}$ gravel & Total material reduction by $20 \%$ \\
\hline Channel design & Concrete surface & Grass surface \\
\hline Number of basins & $14\left(99,942 m^{3}\right)$ & $1\left(100,000 \mathrm{~m}^{3}\right)$ \\
\hline
\end{tabular}


895 Table 5. Volume of runoff from the different domains managed by single 896 elements, and the resulting allocation factors.

\begin{tabular}{|c|c|c|c|c|c|c|c|c|}
\hline & \multirow{2}{*}{\multicolumn{2}{|c|}{ Element }} & \multicolumn{3}{|c|}{ Allocation factors: volume-based } & \multicolumn{3}{|c|}{ Allocation factors: importance-based } \\
\hline & & & Domain A & Domain B & Domain C & Domain A & Domain B & Domain C \\
\hline \multirow{5}{*}{$\sum_{U}^{0}$} & Roads & Channels & $0 \%$ & $96 \%$ & $4 \%$ & $0 \%$ & $50 \%$ & $50 \%$ \\
\hline & & Green areas & $100 \%$ & $0 \%$ & $0 \%$ & $100 \%$ & $0 \%$ & $0 \%$ \\
\hline & Parks & Lowered areas & $0 \%$ & $98 \%$ & $2 \%$ & $0 \%$ & $50 \%$ & $50 \%$ \\
\hline & & Drainage layers & $0 \%$ & $98 \%$ & $2 \%$ & $0 \%$ & $50 \%$ & $50 \%$ \\
\hline & Pipes & Concrete \& PE pipes & $0 \%$ & $96 \%$ & $4 \%$ & $0 \%$ & $50 \%$ & $50 \%$ \\
\hline \multirow{3}{*}{$\begin{array}{l}\text { હ } \\
\text { ஸ }\end{array}$} & Basins & Sub-surface basins & $0 \%$ & $100 \%$ & $0 \%$ & $0 \%$ & $100 \%$ & $0 \%$ \\
\hline & Pipes & Concrete pipes & $75 \%$ & $24 \%$ & $1 \%$ & $33 \%$ & $33 \%$ & $33 \%$ \\
\hline & WWTP & Wastewater treatment & $93 \%$ & $7 \%$ & $0 \%$ & $50 \%$ & $50 \%$ & $0 \%$ \\
\hline
\end{tabular}

897 
898 Table 6. Quantities of the most important materials in both alternatives. 899 The complete inventory is provided in the supporting information.

\begin{tabular}{c|cccccccc}
\hline Material & $\begin{array}{c}\text { Concrete } \\
{[\mathrm{t}]}\end{array}$ & $\begin{array}{c}\text { Steel } \\
{[\mathrm{t}]}\end{array}$ & $\begin{array}{c}\text { Asphalt } \\
{[\mathrm{t}]}\end{array}$ & $\begin{array}{c}\text { Bitumen } \\
{[\mathrm{t}]}\end{array}$ & $\begin{array}{c}\text { Gravel } \\
{[\mathrm{t}]}\end{array}$ & $\begin{array}{c}\text { Clay } \\
{[\mathrm{t}]}\end{array}$ & $\begin{array}{c}\text { Grass } \\
\text { seeds [t] }\end{array}$ & $\begin{array}{c}\text { Total } \\
\text { transport } \\
{[\text { tons.km] }}\end{array}$ \\
\hline $\begin{array}{c}\text { Cloudburst } \\
\text { Management } \\
\quad \text { Plan }\end{array}$ & 40,905 & - & - & - & 29,102 & 3,392 & 12 & $9,761,526$ \\
$\begin{array}{c}\text { Sub-surface } \\
\text { alternative }\end{array}$ & 46,355 & 4,497 & 17,586 & 3,920 & 16,408 & - & - & $19,013,544$ \\
\hline 900 & & & & & & & &
\end{tabular}




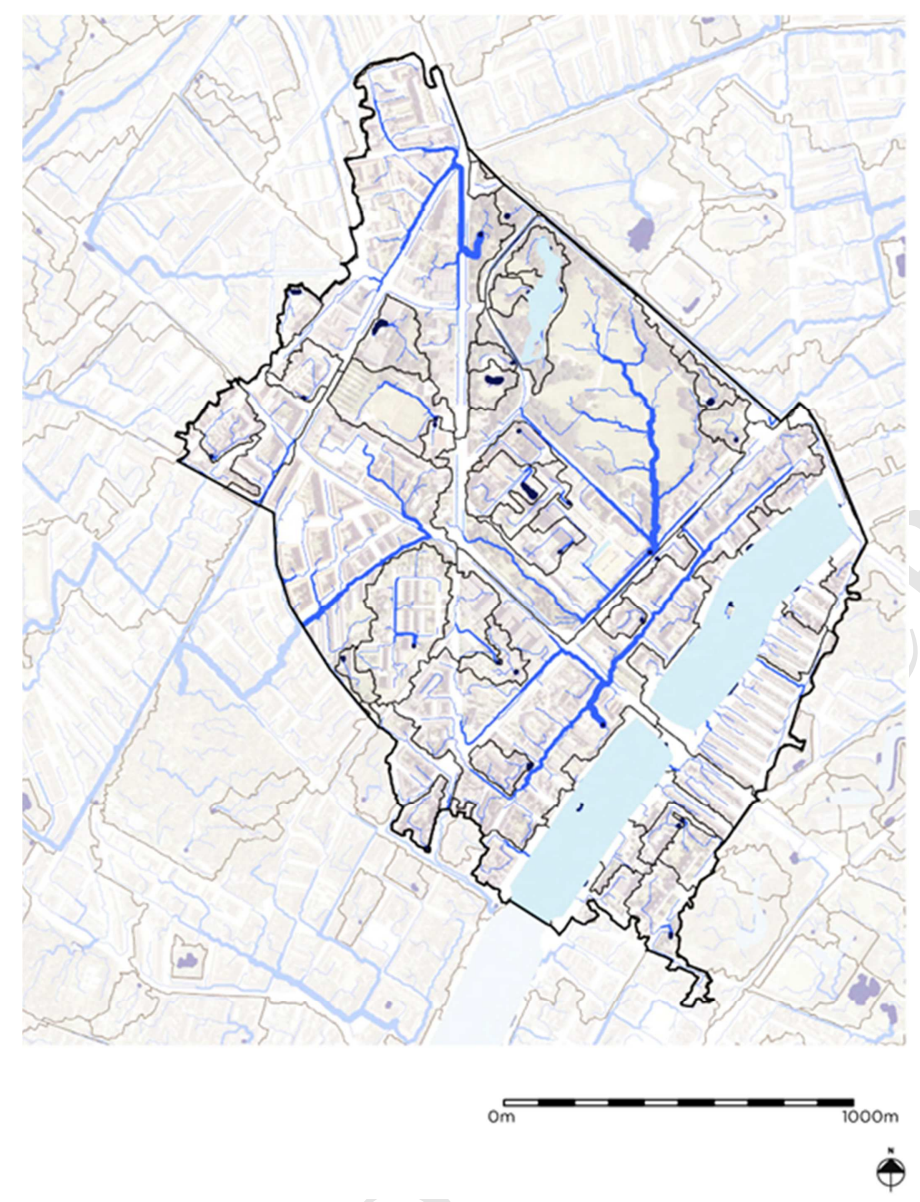

901

902 Fig. 1. Water flow in the Nørrebro catchment (courtesy of Rambøll \& 903 Atelier Dreiseitl). 


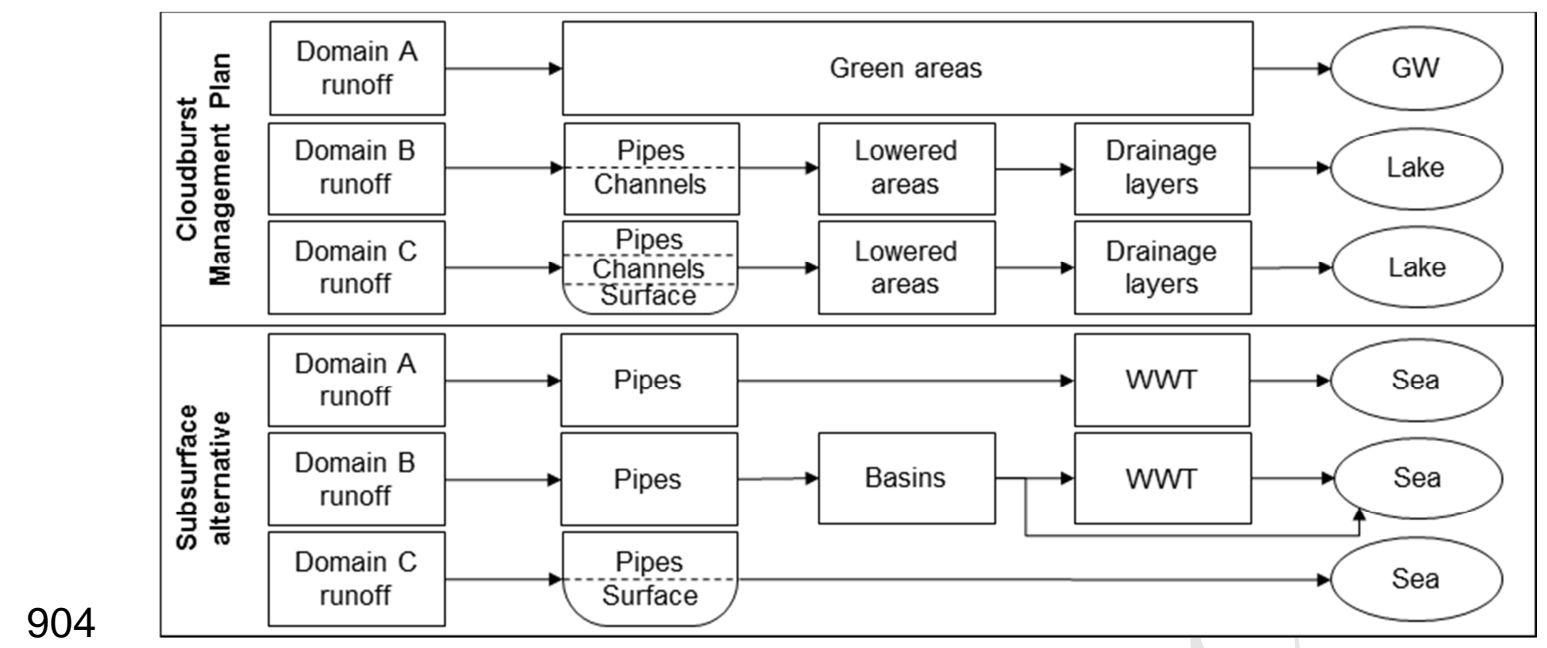

905 Fig. 2. Runoff flow from different rain domains through the system, for the

906 Cloudburst Management Plan and the sub-surface alternative. 


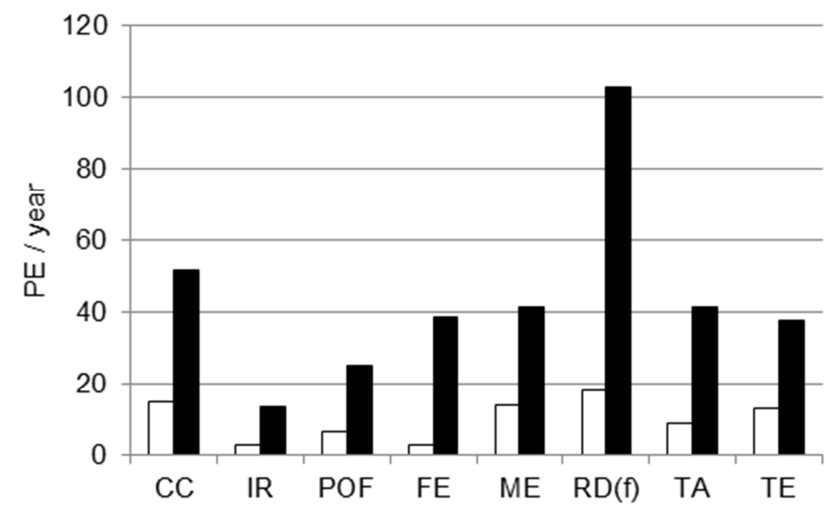

907

Cloudburst Management Plan

Subsurface alternative

908 Fig. 3. Normalised environmental impacts for the Cloudburst Management

909 Plan (CMP) and the sub-surface alternative (SSA) per year. Impact

910 category abbreviations: climate change (CC), ionising radiation (IR),

911 photochemical oxidant formation (POF), freshwater eutrophication (FE),

912 marine eutrophication (ME), resource depletion (fossil) $(\mathrm{RD}(\mathrm{f})$ ), terrestrial

913 acidification (TA), terrestrial eutrophication (TE). 
Cloudburst Management Plan:
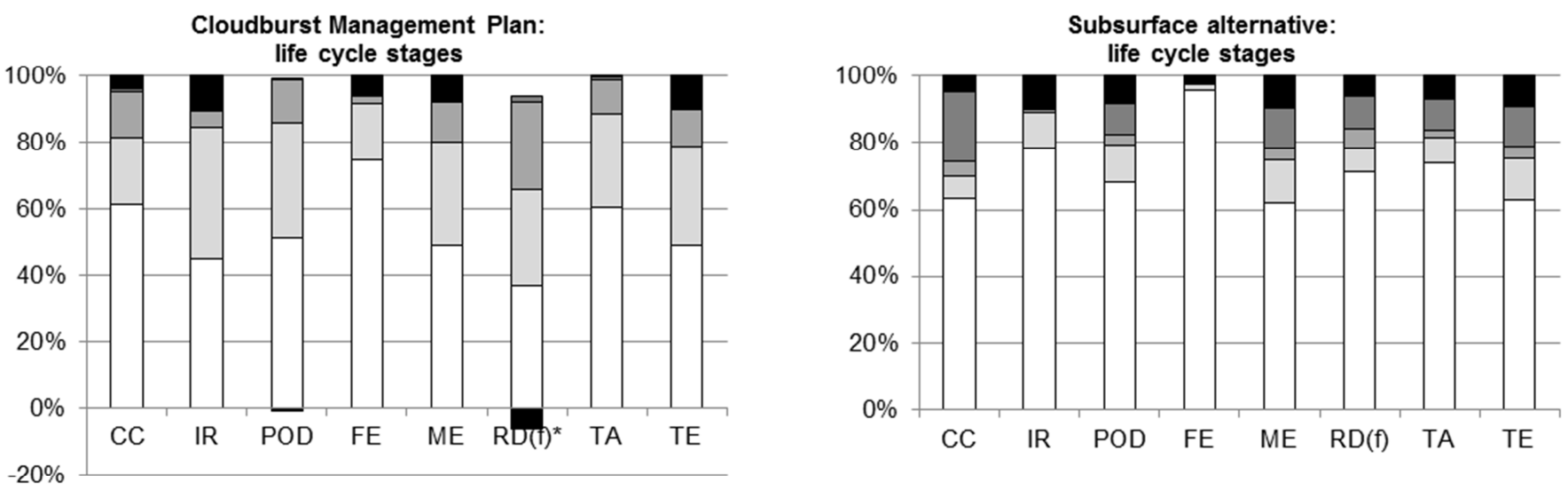

$\square$ Material production $\square$ Transport

Construction

Operation

Decomm. \& disposal

Cloudburst Management Plan:
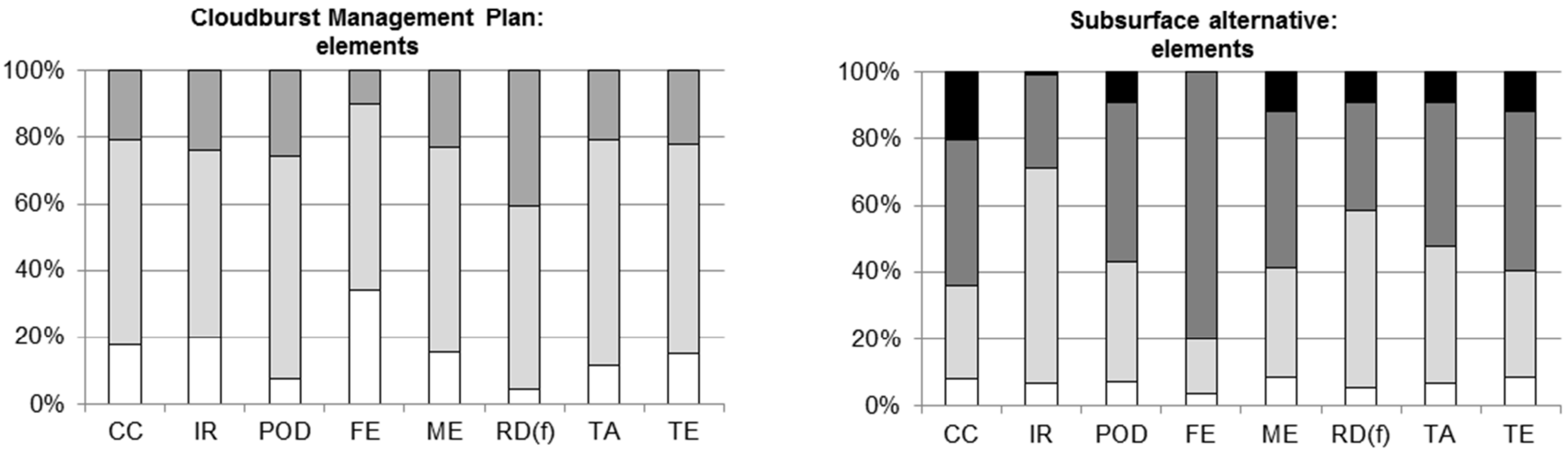

$\square$ Pipes

Roads

Parks (only CMP)

Basins (only SSA)

WWTP (only SSA)

915 Fig. 4. Contribution of the single life cycle stages and system elements to

916 the total environmental impacts of the Cloudburst Management Plan and

917 sub-surface alternative. *Negative impacts result from reduced resource

918 consumption, due to the recycling of polyethylene. Refer to Fig. 2 for

919 abbreviations. 


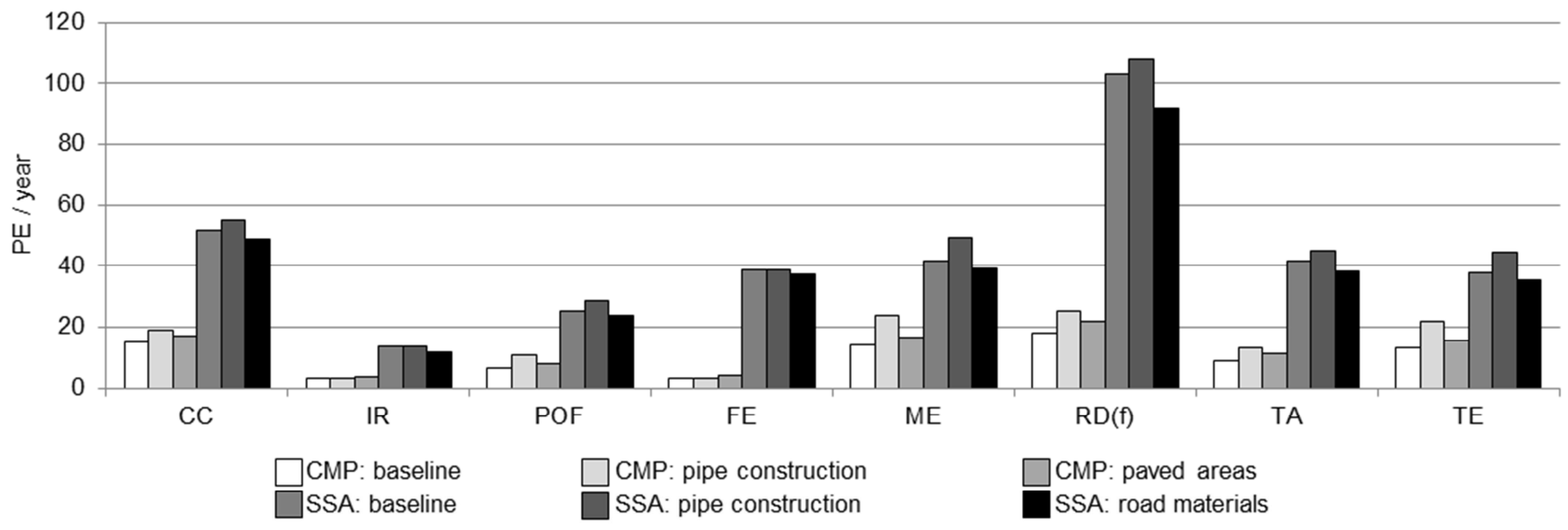

921 Fig. 5. Normalised environmental impacts of the Cloudburst Management 922 Plan (CMP) and sub-surface alternative (SSA) baseline scenario and four 923 alternatives with varying input parameters. Refer to Fig. 2 for 924 abbreviations. 


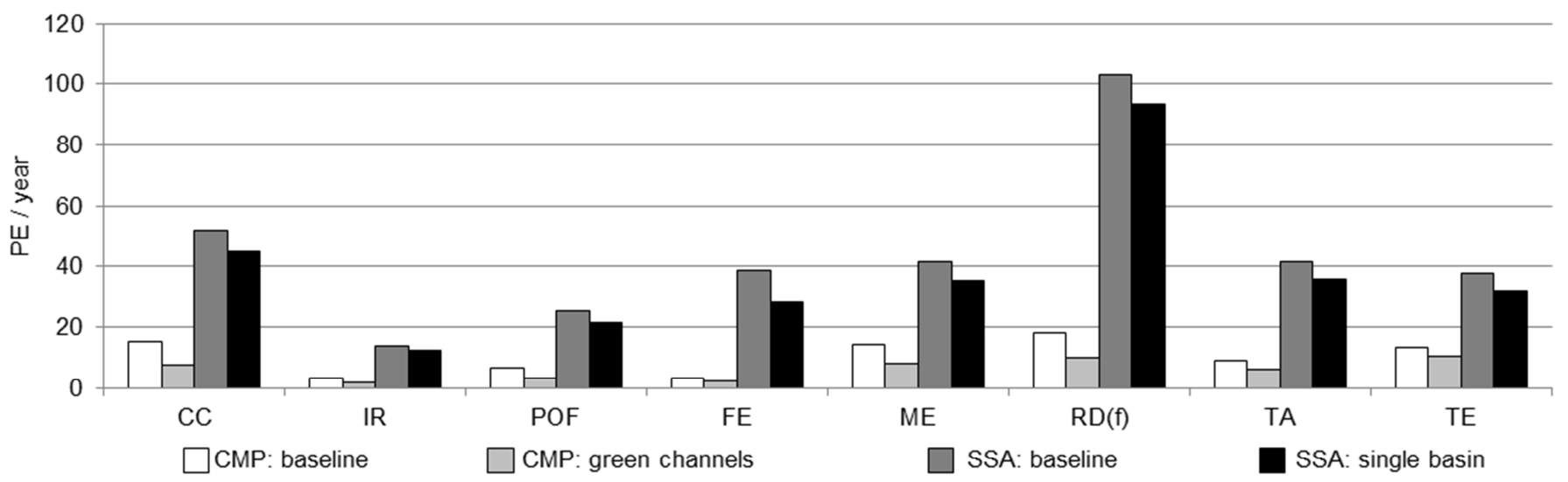

926 Fig. 6. Normalised environmental impacts of the Cloudburst Management

927 Plan (CMP) and the sub-surface alternative (SSA) baseline scenarios and

928 two structurally different scenarios. Refer to Fig. 2 for abbreviations. 

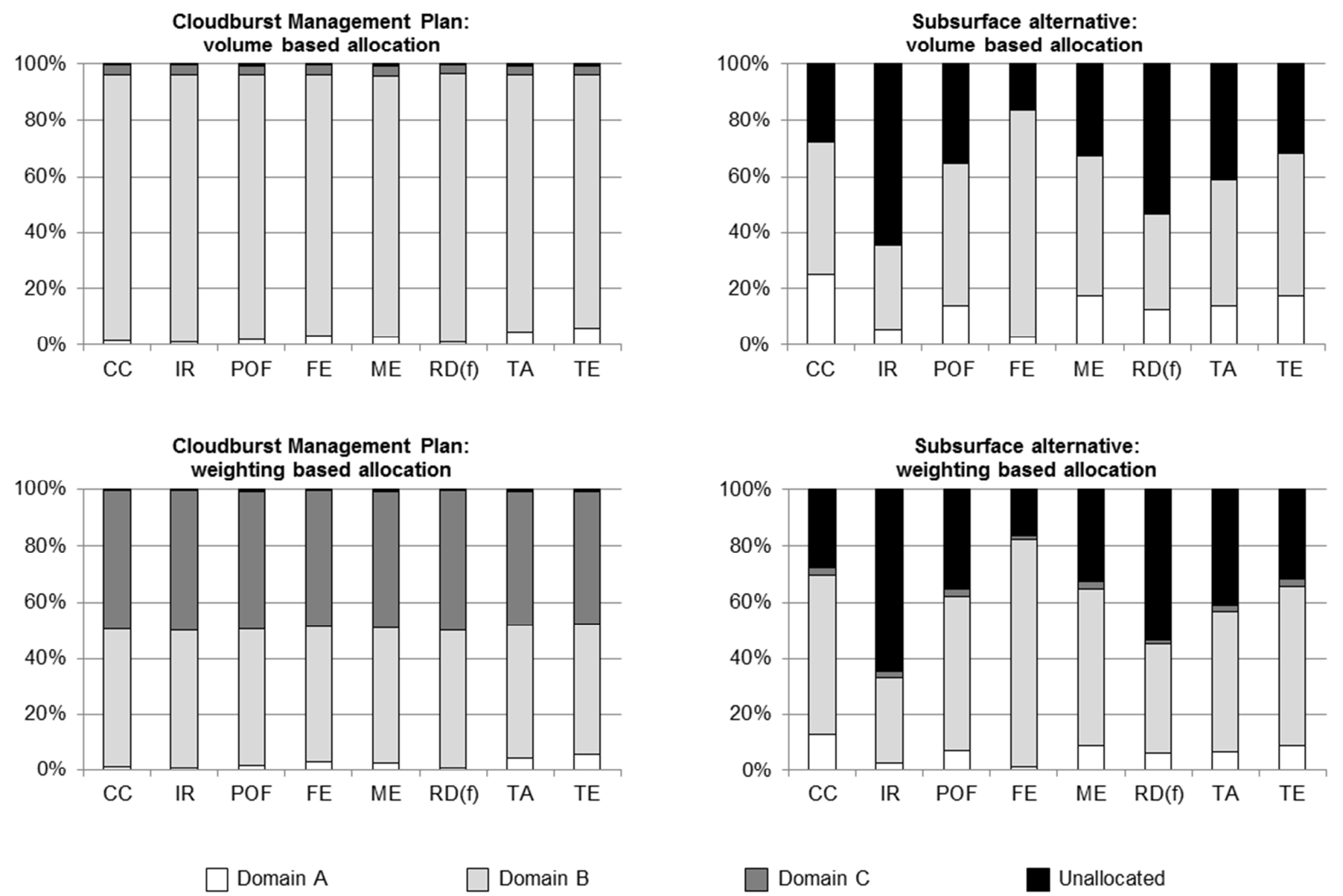

930 Fig. 7. Environmental impacts of the Cloudburst Management Plan and a

931 sub-surface alternative, allocated to different rain domains based on water

932 volume and the weighting of flood safety targets. Refer to Fig. 2 for 933 abbreviations. 


\section{Life cycle assessment of stormwater management in the context of climate change adaptation}

Sarah Brudler, Karsten Arnbjerg-Nielsen, Michael Zwicky Hauschild, Martin Rygaard

\section{Highlights}

- Environmental impacts of climate change adaptation strategies are assessed

- A life cycle assessment is conducted on a large -scale strategy for the first time

- Comparability is ensured through equal flood safety level definitions

- Impacts are allocated to different flood safety levels 